\title{
Municipalities and the promotion of architectural accessibility
}

As autarquias e a promoção da acessibilidade arquitetónica

Los ayuntamientos y la promoción de la accesibilidad arquitetónica

Rute Salomé da Silva Pereira* (D); Maria Manuela Ferreira Pereira da Silva Martins** (D); Bárbara Pereira Gomes***; Soraia Dornelles Schoeller**** (D); José Alberto Laredo-Aguilera***** (D); Isabel Ribeiro ${ }^{* * * * * *}$; Paulo Cunha*******

\section{Abstract}

Background: Architectural barriers have a significant impact on the daily activities of people with reduced mobility.

Objectives: To understand the weaknesses and/or opportunities in the responses of local authorities to eliminate the architectural barriers for people with reduced mobility in their social and residential context.

Methodology: A descriptive, exploratory study was conducted with a sample of 21 parish council presidents from two municipalities using an accidental non-probabilistic sampling method.

Results: In this sample, $76.2 \%$ of parish council presidents do not know how many people with disabilities live in their parish. The elimination of architectural barriers focused on accessible sidewalks and pedestrian routes (80\%), pedestrian crossings (75\%), access to public parks and gardens (70\%), and access to cemeteries and markets $(70 \%)$. Other equipment, even educational ones, represent less than $50 \%$.

Conclusion: Some public spaces still have architectural barriers. There is little cooperation between health professionals and society to promote accessibility.

Keywords: rehabilitation nursing; architectural accessibility; local government; disabled persons; mobility limitation

\section{Resumo}

Enquadramento: As barreiras arquitetónicas assumem um peso importante na prossecuçáo das atividades de vida diária para pessoas com mobilidade condicionada. Objetivos: Compreender as fragilidades e/ou potencialidades das respostas das autarquias locais para abolir barreiras arquitetónicas para pessoas com mobilidade condicionada quando inseridas no seu contexto social e habitacional.

Metodologia: Estudo descritivo, exploratório, com uma amostra de 21 presidentes de junta de dois municípios, a partir de uma amostragem náo probabilística acidental.

Resultados: Da amostra, 76,2\% presidentes de junta não sabem quantas pessoas com deficiência vivem na sua freguesia. A eliminação de barreiras arquitetónicas incidiu sobre passeios e percursos pedonais acessíveis $(80 \%)$, passadeiras $(75 \%)$, acesso a parques e jardins públicos $(70 \%)$ e a cemitérios e mercado $(70 \%)$. Os restantes equipamentos, mesmo os educacionais, têm representaçôes abaixo de $50 \%$.

Conclusão: Subsistem espaços de uso público com barreiras arquitetónicas. Existe pouca articulação entre profissionais de saúde e a sociedade para a promoção da acessibilidade.

Palavras-chave: enfermagem em reabilitação; estruturas de acesso; governo local; pessoas com deficiência; limitação da mobilidade

*MSc., Nurse Specialist in Rehabilitation Nursing, Nursing School of Porto, 4200-07 Porto, Portugal [rutesalomesilvapereira@gmail.com]. (1) https://orcid.org/0000-0002-44680787. Contribution to the article: planning data collection, analysis and article writing and revision. Address for correspondence: Rua Eduardo Madeira $\mathrm{n}^{\circ} 155 \mathrm{R} / \mathrm{C}$ esq $4410-432 \mathrm{VNG}$ revision. Address for correspondence: Rua Eduardo Madeira $\mathrm{n}^{\circ} 155 \mathrm{R} / \mathrm{C}$ esq $4410-432 \mathrm{VNG}$ tins@esenf.pt].D https://orcid.org/0000-0003-1527-9940. Contribution to the article: plantins@esent.pt].. hitps://orcid.org/0000-0003-1527-9940. Contr.

ning, data collection, analysis, and article writing and revision. mes@esenf.pt].Contribution to the article: article writing and revision.

***:Ph.D., Coordinating Professor, Federal University of Santa Catarina, 88040-370, Santa *atarina, Brasil [soraiadornelleschoeller@ogmail.com1. (D) https://orcid.org/0000-0002-07583777. Contribution to the article: article writing and revision.

3777. Contribution to the article: article writing and revision. rapy, Speech Therapy and Nursing, 45600, Toledo, Espanha [josealbertolaredo@uclm.es]. rapy, Speech Therapy and Nursing, 45000, oledo, Espanha josealbertolaredo@uclm.es.. https:/orcid.org/0000-0002-3601-3584. Contribution to the article: article writing and revision. ribeiro59@gmail.com]. Contribution to the article: article writing and revision. ribeiro59@gmail.com. Contribution to the article: article writing and revision. Portugal [paulocunha.psd@gmail.com]. Contribution to the article: data collection, article writing and revision.

\section{Resumen}

Marco contextual: Las barreras arquitectónicas asumen un peso importante en la realización de las actividades de la vida diaria de las personas con movilidad reducida. Objetivos: Comprender las fragilidades y/o potencialidades de las respuestas de los ayuntamientos locales para abolir barreras arquitectónicas para personas con movilidad condicionada cuando se encuentran en su contexto social y habitacional.

Metodología: Estudio descriptivo, exploratorio, con una muestra de 21 presidentes de junta de dos municipios, a partir de un muestreo no probabilístico accidental.

Resultados: De la muestra, el 76,2\% de los presidentes de junta no sabe cuántas personas con discapacidad viven en su barrio. La eliminación de barreras arquitectónicas incidió sobre paseos y zonas peatonales accesibles $(80 \%)$, pasos de peatones $(75 \%)$, acceso a parques y jardines públicos $(70 \%)$ y a cementerios y mercados (70\%). Los restantes equipamientos, incluso los educacionales, tienen representaciones por debajo del $50 \%$.

Conclusión: Subsisten espacios de uso público con barreras arquitectónicas. Hay poca articulación entre los profesionales de la salud y la sociedad para promover la accesibilidad.

Palabras clave: enfermería en rehabilitación; estructuras de acceso; gobierno local; personas con discapacidad; limitación de la movilidad 


\section{Introduction}

The rehabilitation nurse "promotes mobility, accessibility, and social participation" (Regulamento n. ${ }^{\circ} 125 / 2011$, p. 8659) through their own knowledge about specific legislation, the enhancement of the community's awareness about inclusive practices, the identification and elimination of architectural barriers, and the issuing of technical-scientific opinions on social structures and equipment in the community.

People with reduced mobility are faced with architectural barriers in their residential areas, so it is important to broaden the study of this phenomenon to other agents with a level of responsibility in this process. The analysis of parish council presidents' perceptions will allow understanding the local reality and meeting the following objectives: to understand the weaknesses and/or opportunities in the responses of local authorities to eliminate architectural barriers for people with reduced mobility in their social and residential context; to describe parish council presidents' perception of the importance of their role in architectural accessibility; to identify parish council presidents' constraints to the elimination of architectural barriers; and to characterize municipalities regarding accessibility based on parish council presidents' perceptions.

This study aims to contribute to improving rehabilitation nurses' intervention through the development of innovative partnerships and interventions for meeting the real needs of people with reduced mobility.

\section{Background}

The 2011 census revealed that the main difficulty was related to walking, followed by the difficulty in seeing (Instituto Nacional de Estatística, 2012). For people with disabilities or reduced mobility, architectural barriers can make a difference between exclusion and social participation (Gamache et al., 2017).

In Decree-law no. 163/2006 (Decreto-Lei no 163/2006), which established the regime of accessibility to public buildings and facilities, public roads and residential buildings, people with reduced mobility are defined as those who require a wheelchair, who are unable to walk or walk long distances, who have sensory difficulties or who are temporarily limited (pregnant women, children, and older people). For all these people, architectural barriers in spaces where they develop their daily activities are insurmountable, conditioning or preventing mobility (Bárrios \& Fernandes, 2014).

Both in Portugal and in the rest of Europe, strategies have been developed for the promotion of architectural accessibility, including one of the proposals of the $21^{\text {st }}$ Constitutional Government of Portugal: the "Inclusive Territories" program. According to Falcato (2017), local authorities play an important role in the elimination of barriers, with an emphasis on the promotion of an accessible, barrier-free environment. Local authorities should expand their activities, going beyond the areas of infrastructure and basic equipment. It is important to create/strengthen synergies between the municipal power and the health sector with a view to promoting the health and accessibility of people with reduced mobility.

\section{Research questions}

Do parish council presidents recognize the importance of their role in the elimination of the architectural barriers in public spaces, collective equipment, and public buildings in their area of intervention? What are parish council presidents' constraints to eliminating architectural barriers? What were parish council presidents' interventions towards the elimination of architectural barriers for people with reduced mobility during their municipal mandate? Which architectural barriers did the parish council presidents identify as being problematic for people with reduced mobility to access public places? What is the support provided by parish council presidents to people with reduced mobility for the elimination of architectural barriers in various contexts?

\section{Methodology}

This is a descriptive, exploratory study, using the quantitative paradigm.

The study was developed in the municipalities of Porto and Vila Nova de Famalicão, with 
a population composed of 41 parish council presidents. An accidental nonprobability sampling method was used because the sample was composed of individuals who were accessible. The sample was composed of 17 parish council presidents of the municipality of Vila Nova de Famalicão and four from the municipality of Porto, in a total of 21 presidents with a representation of approximately $50 \%$ in both municipalities.

For data collection, an ad hoc self-administered questionnaire was applied to the parish council presidents. The level of understanding and the content and questions of this questionnaire had been previously assessed with a group of four parish council presidents who were not part of the study.

The following variables were considered: sociodemographic characteristics; importance of architectural barriers; the local authorities' position towards architectural accessibility; elimination of architectural barriers by area of intervention; constraints to the elimination of barriers; problematic architectural barriers in the access to public places; support provided by the parish council to people with reduced mobility; opinion on the compliance with Decree-Law No. 163/2006; and accessible routes in public places.

Data were collected in collaboration with the municipalities between January and July 2017. Participants received an email message with information about the research and its objectives, as well as the questionnaire and the informed consent form (in PDF) as an attachment. These documents were returned after being completed, without any contact between researchers and participants.

The study was approved by the Ethics Committee of the Nursing School of Porto on 31 January 2017, through Opinion No. $11 / 2017$.

Data were statistically analyzed using IBM SPSS Statistics software, version 20.0. Descriptive statistics were used to calculate absolute $(N)$ and relative frequencies (\%); measures of central tendency (mean and median); and measures of dispersion (minimum, maximum, and standard deviation).

\section{Results}

The sample was composed of 20 male participants $(95.2 \%)$ and one female participant $(4.8 \%)$ with a mean age of 55 years. They had been working as parish council presidents, on average, for 9.24 years and more than half of them (52.4\%) for 3 to 7 years. The majority of them had completed secondary education $(47.6 \%)$. As regards the distribution of the sample per municipality, $81 \%$ of them were from Vila Nova de Famalicão and 19\% were from the municipality of Porto.

Parish council presidents considered it to be very important $(42.9 \%)$ and extremely important $(57.1 \%)$ to eliminate architectural barriers as a way of promoting the accessibility of people with reduced mobility; $42.9 \%$ of them agree and $52.4 \%$ strongly agree that parish councils and their presidents have a strategic importance, given their close contact with the citizens, in the promotion of accessibility for an inclusive municipality.

In relation to the number of people with physical disabilities, $76.2 \%$ of them reported not knowing how many people had physical disabilities in their area of intervention. On the other hand, those who reported knowing how many people had disabilities (23.8\%) identified an average of 7.20 people, with a standard deviation of 3.701 people with disabilities, being that there is a minimum of three and a maximum of 12 people with physical disabilities by parish. With regard to public places with architectural barriers in the parish council's area of intervention, $66.7 \%$ of them reported that there were still some public places with architectural barriers (for example, the parish councils' offices or health care centers).

In this sample, $95.2 \%$ of the parish council presidents reported having implemented interventions for the elimination of architectural barriers, whereas $4.8 \%$ of them did not implement any intervention.

According to Table 1, the most common interventions were done on accessible sidewalks and pedestrian routes (80\%), pedestrian crossings $(75 \%)$, access to public parks and gardens $(70 \%)$, and access to cemeteries and the market $(70 \%)$. 
Table 1

Elimination of architectural barriers by area of intervention

\begin{tabular}{lcccccc}
\hline & \multicolumn{3}{c}{ Parish council president $(N=20)$} \\
\cline { 2 - 6 } Dimensions & \multicolumn{2}{c}{ Yes } & \multicolumn{2}{c}{ No } & \multicolumn{2}{c}{ Not applicable } \\
\cline { 2 - 6 } & $N$ & $\%$ & $N$ & $\%$ & $N$ & $\%$ \\
\hline Accessible sidewalks and pedestrian routes & 16 & 80 & 2 & 10 & 2 & 10 \\
Public sanitary facilities & 10 & 50 & 9 & 45 & 1 & 5 \\
Removal/changes in the location of urban furniture in public roads & 8 & 40 & 5 & 25 & 7 & 35 \\
Access to public museums, theaters, cinemas, and libraries & 2 & 10 & 7 & 35 & 11 & 55 \\
Access to public education institutions & 10 & 50 & 4 & 20 & 6 & 30 \\
Access to public sports facilities & 9 & 45 & 4 & 20 & 7 & 35 \\
Mechanical access to the public swimming pool & 1 & 5 & 3 & 15 & 16 & 80 \\
Changes in vertical/horizontal signs & 5 & 25 & 9 & 45 & 6 & 30 \\
Access to equipment (cemetery and market) & 14 & 70 & 5 & 25 & 1 & 5 \\
Access to public parks and gardens & 14 & 70 & 3 & 15 & 3 & 15 \\
Pedestrian crossings & 15 & 75 & 3 & 15 & 2 & 10 \\
\hline
\end{tabular}

Parish council presidents reported facing the following constraints: lack of compliance with the legislation on accessibility (38.1\%); lack of financial resources $(47.6 \%)$, training on accessibility $(38.1 \%)$ and technical specifications in accordance with Decree-Law No. 163/2006 (38.1\%); technical support to substantiate their decision (38.1\%); and citizens' participation $(33.3 \%)$. The most problematic architectural barriers in the access to public places were: inadequate parking in the sidewalks and lack of lifting platforms and elevators for people using wheelchairs (Figure 1).

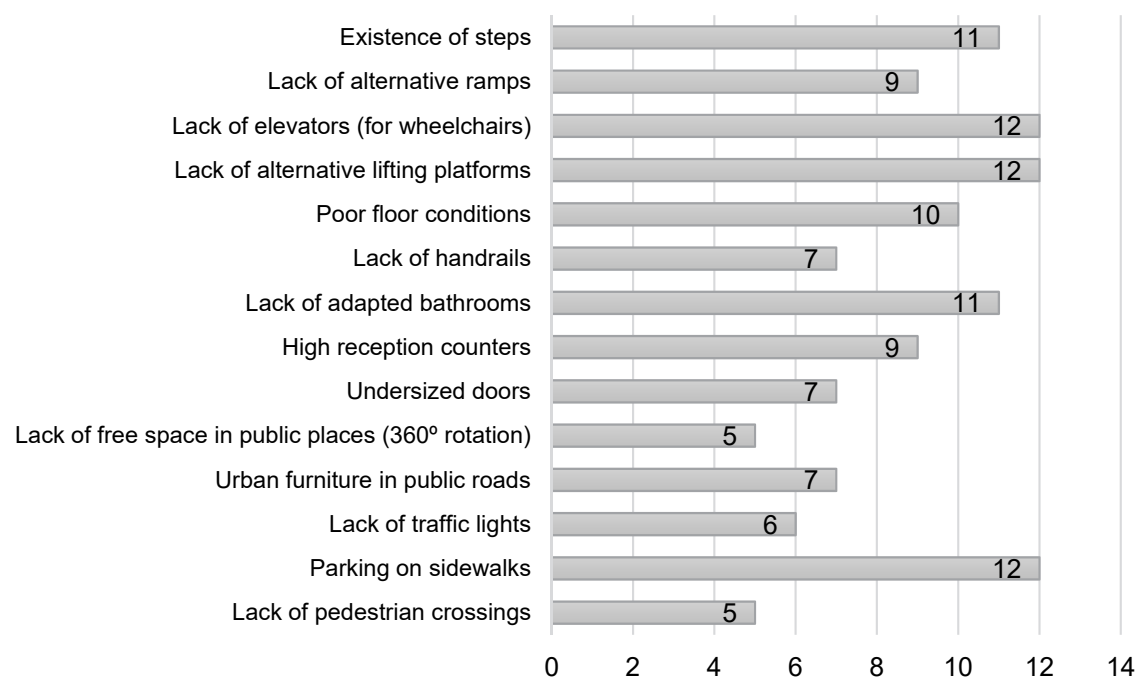

Figure 1. Level of agreement with the existence of architectural barriers in the access to public places. 
With regard to the compliance with the legal provisions of Decree-Law no. 163/2006, parish council presidents had to answer 35 items in total and, of these, only eight items showed a higher incidence of the response option yes: the sidewalks' surface is stable, durable, and firm (38.1\%); the front/side access to the shelter has a width $\geq 0.80 \mathrm{~m}$ and no obstacles (42.9\%); the drains allow for the quick drainage of rainwater and pavement drying (42.9\%); the green signal for pedestrian crossings allows pedestrians to cross at a speed of $0.4 \mathrm{~m} /$ second (38.1\%); the pedestrian pushbutton is located at $0.8 \mathrm{~m}-1.2 \mathrm{~m}$ above the floor $(52.4 \%)$; the limits of the pedestrian crossings are marked on the ground with a different texture or contrasting color $(38.1 \%)$; and people using wheelchairs can move around in the common areas of buildings (52.4\%). Thus, according to the dimensions under analysis, the majority of the provisions in this Decree-Law are not being met or at least fully met.

With regard to citizens' daily life, parish council presidents reported that the following places were easily accessible: parish council, cemetery, and service stations (71.4\%), followed by nursing homes/senior residences/day centers (61.9\%). The following places were reported as not being accessible: parish council (9.5\%), nursery/kindergarten $(4.8 \%), 1^{\text {st }}$ to $9^{\text {th }}$ grade schools (4.8\%), sports facilities/football fields/ public swimming pool (4.8\%), and museums/ theaters $(4.8 \%)$. These results reveal some significant disparities given that some places were accessible while others remained inaccessible.

Table 2 shows that the access to the train station/bus station was the only one which was reported as being easily accessible (28.6\%), with the remaining presidents reporting that their parish had no train station/bus station (71.4\%).

Table 2

Accessible public places

\begin{tabular}{|c|c|c|c|c|c|c|c|c|c|c|c|c|}
\hline \multirow[t]{2}{*}{ Dimensions } & \multicolumn{2}{|c|}{ Inaccessible } & \multicolumn{2}{|c|}{$\begin{array}{l}\text { Accessible } \\
\text { only with } \\
\text { help }\end{array}$} & \multicolumn{2}{|c|}{$\begin{array}{l}\text { Difficult } \\
\text { access }\end{array}$} & \multicolumn{2}{|c|}{ Easy access } & \multicolumn{2}{|c|}{$\begin{array}{c}\text { Not } \\
\text { applicable }\end{array}$} & \multicolumn{2}{|c|}{ Total } \\
\hline & $N$ & $\%$ & $N$ & $\%$ & $N$ & $\%$ & $N$ & $\%$ & $N$ & $\%$ & $N$ & $\%$ \\
\hline Parish council office & 2 & 9.5 & 2 & 9.5 & 2 & 9.5 & 15 & 71.4 & 0 & 0.0 & 21 & 100 \\
\hline Post office & 0 & 0.0 & 3 & 14.3 & 1 & 4.8 & 6 & 28.6 & 11 & 52.4 & 21 & 100 \\
\hline $\begin{array}{l}\text { Church or other place } \\
\text { of worship }\end{array}$ & 0 & 0.0 & 7 & 33.3 & 3 & 14.3 & 11 & 52.4 & 0 & 0.0 & 21 & 100 \\
\hline Cemetery & 0 & 0.0 & 3 & 14.3 & 3 & 14.3 & 15 & 71.4 & 0 & 0.0 & 21 & 100 \\
\hline $\begin{array}{l}\text { Health care center/other } \\
\text { health care facility }\end{array}$ & 0 & 0.0 & 4 & 19 & 2 & 9.5 & 6 & 28.6 & 9 & 42.9 & 21 & 100 \\
\hline Nursery/kindergarten & 1 & 4.8 & 5 & 23.8 & 3 & 14.3 & 12 & 57.1 & 0 & 0.0 & 21 & 100 \\
\hline $1^{\text {st }}$ to $9^{\text {th }}$ grade schools & 1 & 4.8 & 4 & 19 & 4 & 19 & 12 & 57.1 & 0 & 0.0 & 21 & 100 \\
\hline Library & 0 & 0.0 & 3 & 14.3 & 0 & 0.0 & 3 & 14.3 & 15 & 71.4 & 21 & 100 \\
\hline Museums and theaters & 1 & 4.8 & 1 & 4.8 & 1 & 4.8 & 4 & 19 & 14 & 66.7 & 21 & 100 \\
\hline $\begin{array}{l}\text { Sports facilities/football } \\
\text { fields/public swimming } \\
\text { pool }\end{array}$ & 1 & 4.8 & 1 & 4.8 & 5 & 23.8 & 11 & 52.4 & 3 & 14.3 & 21 & 100 \\
\hline Market & 0 & 0.0 & 3 & 14.3 & 0 & 0.0 & 4 & 19 & 14 & 66.7 & 21 & 100 \\
\hline $\begin{array}{l}\text { Nursing homes/senior } \\
\text { residences/day centers }\end{array}$ & 0 & 0.0 & 3 & 14.3 & 1 & 4.8 & 13 & 61.9 & 4 & 19 & 21 & 100 \\
\hline Train station/bus station & 0 & 0.0 & 0 & 0.0 & 0 & 0.0 & 6 & 28.6 & 15 & 71.4 & 21 & 100 \\
\hline Coffee shops & 0 & 0.0 & 8 & 38.1 & 8 & 38.1 & 5 & 23.8 & 0 & 0.0 & 21 & 100 \\
\hline $\begin{array}{l}\text { Supermarket/conve- } \\
\text { nience stores }\end{array}$ & 0 & 0.0 & 7 & 33.3 & 6 & 28.6 & 6 & 28.6 & 2 & 9.5 & 21 & 100 \\
\hline
\end{tabular}




\begin{tabular}{lcccccccccccc}
\hline Service stations & 0 & 0.0 & 2 & 9.5 & 2 & 9.5 & 15 & 71.4 & 2 & 9.5 & 21 & 100 \\
Banks & 0 & 0.0 & 3 & 14.3 & 1 & 4.8 & 4 & 19 & 13 & 61.9 & 21 & 100 \\
ATMs & 0 & 0.0 & 6 & 28.6 & 3 & 14.3 & 9 & 42.9 & 3 & 14.3 & 21 & 100 \\
\hline
\end{tabular}

The most prevalent type of support which may be requested by the person with reduced mobility to the parish councils for the elimination of architectural barriers in pedestrian routes were another type of support (42.9\%); technical support to eliminate architectural barriers in the access to built-up areas environment (38.1\%); and another type of support to eliminate barriers in the areas surrounding their homes (38.1\%).

With regard to the elimination of architectural barriers in public facilities, most of them answered that this was not a responsibility of the parish council $(38.1 \%)$, and neither were the construction works inside the homes of people with reduced mobility to promote accessibility $(47.6 \%)$, as can be seen in Table 3 .

Table 3

Support provided by the parish councils to eliminate architectural barriers

\begin{tabular}{|c|c|c|c|c|c|c|c|c|c|c|}
\hline \multirow[t]{2}{*}{ Dimensions } & \multicolumn{2}{|c|}{$\begin{array}{l}\text { Technical } \\
\text { support }\end{array}$} & \multicolumn{2}{|c|}{$\begin{array}{l}\text { Financial } \\
\text { support }\end{array}$} & \multicolumn{2}{|c|}{$\begin{array}{l}\text { Another type } \\
\text { of support }\end{array}$} & \multicolumn{2}{|c|}{$\begin{array}{c}\text { Not a } \\
\text { responsibility } \\
\text { of the parish } \\
\text { council }\end{array}$} & \multicolumn{2}{|c|}{ Total } \\
\hline & $N$ & $\%$ & $N$ & $\%$ & $N$ & $\%$ & $N$ & $\%$ & $N$ & $\%$ \\
\hline $\begin{array}{l}\text { In pedestrian routes for people with } \\
\text { reduced mobility to perform their } \\
\text { daily activities }\end{array}$ & 6 & 28.6 & 0 & 0.0 & 9 & 42.9 & 6 & 28.6 & 21 & 100 \\
\hline In the access to built-up areas & 8 & 38.1 & 0 & 0.0 & 6 & 28.6 & 7 & 33.3 & 21 & 100 \\
\hline In the areas surrounding their homes & 6 & 28.6 & 0 & 0.0 & 8 & 38.1 & 7 & 33.3 & 21 & 100 \\
\hline In public equipment & 5 & 23.8 & 4 & 19 & 4 & 19 & 8 & 38.1 & 21 & 100 \\
\hline $\begin{array}{l}\text { For construction works inside the } \\
\text { homes to facilitate mobility }\end{array}$ & 3 & 14.3 & 3 & 14.3 & 5 & 23.8 & 10 & 47.6 & 21 & 100 \\
\hline
\end{tabular}

\section{Discussion}

In 2006, Portugal approved the so-called Parity Law, which set a minimum level of representation of $33.3 \%$ for each gender on lists of candidates for the Assembly of the Republic, the European Parliament, and the local elections. Female participation in this study is limited as only one woman was involved in local politics (4.8\%).

With regard to academic qualifications, the results obtained in this study are in line with those obtained at a national level, with a predominance of parish council presidents who had completed secondary education (47.6\%) and higher education (23.8\%), followed by those who had studied up to $9^{\text {th }}$ grade (Tavares, Rodrigues, \& Silva, 2013). In relation to age, the majority of participants were older than 51 years. Most of them had been working as parish council presidents for 3 to 7 years.

Within their legal competences, municipalities, and particularly parish council presidents, are responsible for promoting the accessibility of people with reduced mobility by creating accessible environments through the elimination of architectural barriers, which are an obstacle to both its use by people with reduced mobility and to social participation (Falcato, 2017; Gamache et al., 2017). The majority of parish council presidents consider it to be extremely important to eliminate architectural barriers for people with reduced mobility and most of them agree (42.9\%) and strongly agree $(52.4 \%)$ that parish councils play an important strategic role in the promotion of accessibility. Despite recognizing the importance of eliminating architectural barriers, $23.8 \%$ of parish 
council presidents know how many people with disabilities live in their parish, which demonstrates their involvement and concern; however, $76.2 \%$ were unaware of the number of people with disabilities, revealing a gap in the cooperation between health services and the local support structures.

With regard to the type of support, some parish council presidents reported that it was not their responsibility to eliminate architectural barriers in public facilities $(38.1 \%)$ or inside the homes of people with reduced mobility $(47.6 \%)$.

Fontes and Martins (2015) conducted a study on the lives of people with spinal cord injuries. A total of 93 interviews were performed, of which 28 were performed to persons with spinal cord injury in the initial rehabilitation phase. Of these, 19 reported that they had to move to another home or remodel their homes and that their parish councils had played a significant role in these construction works by offering the materials and, sometimes, the workforce.

In a study conducted in three municipalities of the central region of Portugal to identify their municipal management programs, the authors found a housing program aimed to improve basic housing conditions which took into account the issues of architectural accessibility and included, for example, small repairs inside people's homes (Bárrios \& Fernandes, 2014). In the same study, the authors also found that some municipalities had intervention programs for the environment and the green spaces which included measures for adapting spaces to people with reduced mobility.

It can be highlighted that, although some parish council presidents believed that it was not their responsibility to eliminate architectural barriers inside people's homes or in public facilities, others felt responsible for these interventions and provided support for people to adapt their homes.

The most common type of support provided by parish councils is another type of support for the elimination of barriers in pedestrian routes $(42.9 \%)$ and in the areas surrounding people's homes $(38.1 \%)$ and technical support for the elimination of barriers in the access to built-up areas (38.1\%). Financial support was never mentioned and the lack of financial resources was the most common constraint mentioned by these presidents, which is essential for deciding on the type of support to be provided.

The United Nations' report on the right to adequate housing for persons with disabilities living in cities emphasizes the major importance of local governments in the promotion of independent living through actions plans to ensure access to public services and places without architectural barriers (Szporluk, 2015). Portugal is also a signatory to the Convention on the Rights of Persons with Disabilities.

In fact, $66.7 \%$ of the present study's participants reported that there were still some public places with architectural barriers. These data are corroborated by a study which assessed the architectural barriers in the access to 20 public buildings and revealed that $50 \%$ of them were not accessible (Almeida, Ferreira, \& Figueiredo, 2008).

For this reason, the majority of parish council presidents (95.2\%) had implemented interventions for eliminating architectural barriers, with the exception of one. In a Swedish study on accessibility at a municipal level, 55\% of municipalities reported having implemented measures (Wennberg, Stahl, \& Hydén, 2009). The main areas of intervention are those associated with parish councils' specific competencies, namely the management and maintenance of public playgrounds, cemeteries, streets, and pedestrian pavements. The interventions for eliminating architectural barriers were done mostly on accessible sidewalks and pedestrian routes $(80 \%)$; pedestrian crossings (75\%); access to equipment such as cemeteries and markets (70\%); and access to public parks and gardens $(70 \%)$.

Moreover, in their area of intervention, $42.9 \%$ of parish council presidents reported the existence of steps, and the lack of elevators without appropriate measures for people using wheelchairs and lifting platforms, whilst $38.1 \%$ of them reported the existence of poor floor conditions and lack of sanitary facilities adapted to people with reduced mobility. In a study conducted with primary caregivers of children with cerebral palsy, Pereira, Caribé, Guimarães, and Matsuda (2011) also found that these architectural barriers were the most problematic ones. 
The current legislation suggests the use of the international symbol of access, but $95.2 \%$ of parish councils do not use it. In a study on the conditions of accessibility in 27 schools in Chapecó, Brazil, none of the schools used this symbol (Gallo, Orso, \& Fiório, 2013).

Among the constraints experienced by parish council presidents when attempting to eliminate architectural barriers, the most common difficulty was the lack of financial resources (47.6\%), being that the construction of municipal facilities and other works that incorporate the legislation and the principles of universal design early in the planning stage will save resources over the long term and promote the correct planning of cities (Government of Ontario, 2015).

The lack of training on accessibility and the specifications in Decree-Law No. 163/2006 were also mentioned as difficulties (38.1\%) because the legislation was difficult to interpret, which led to the creation of an instrument to clarify it: the Guide of Accessibility and Mobility for All (Instituto Nacional de Reabilitação, 2010). It is essential to raise parish council presidents' awareness and empower them, as well as improve knowledge transfer for the creation/implementation of inclusive policies.

The lack of citizens' participation $(33.3 \%)$ was also a difficulty, despite being essential to help others within a democratic and participatory culture (Perestrelo, 2012).

The lack of compliance with the legislation on accessibility was another difficulty reported in this study $(38.1 \%)$, given that the legislation allows central, regional, and local public administration (which do not require municipal licensing/authorization) to certify the compliance with legal requirements through an affidavit of responsibility. Moreover, supervision of compliance with the legislation is an additional difficulty because both licensing and supervision of constructions works are often carried out by the city halls, which makes the process inefficient.

Parish council presidents reported that the most easily accessible spaces were the parish council, the cemetery, and the service stations $(71.4 \%)$; however, there are significant disparities, given that some of them have all the accessibility conditions and others remain totally inaccessible or are only accessible with the help of others.
In the study of Lima, Carvalho-Freitas, and Santos (2013), one participant mentioned that she does not go out alone because she is afraid of the conditions of the physical environment in her city, which increases her level of dependence. Other participants reported that they go out on their own but that they ask for the help of other people to overcome some of the barriers, and one participant even reported feeling embarrassed if she has to be carried up the stairs.

This study had some limitations such as sample size and the limitation to two municipalities. The sample is only representative of the municipalities of Porto and Vila Nova de Famalicão, thus other municipalities and other contexts should be analyzed for these results to be generalized. Efforts were made to contact other city halls for the development of this study but none of them replied.

\section{Conclusion}

This study showed that one of the opportunities was the fact that the parish council presidents considered it important to eliminate the architectural barriers and that most of them agreed with the importance of their strategic role in the promotion of architectural accessibility, given their proximity to the citizens.

The recognition of the need for training on accessibility is an opportunity to be put into practice by the local authorities. Rehabilitation nurses can provide this training because they have the technical-scientific knowledge and can raise their awareness about the impact of architectural barriers on the quality of life of these people as these barriers can often be eliminated with simple measures and a proper resource planning.

With regard to the municipalities' responses, there is a need to create partnerships and work in cooperation with the health structures, namely with rehabilitation nurses who, as part of long-term care teams, should establish protocols for identifying persons with disabilities/ reduced mobility. This is an important strategy given that only five of the parish council presidents knew the number of people with physical disabilities in their area of intervention.

The lack of financial resources was identified 
as a weakness; however, this reality calls for the need to make decisions that require a large investment in sustainable planning and knowledge sharing between several professionals so that decisions are not taken in isolation. In addition, the lack of technical support to substantiate the decision-making process is also a weakness, so it is important for rehabilitation nurses to be part of the executive bodies of city halls and/or parish councils given that they have a sound knowledge about people with reduced mobility and their functional capacity, as well as about legislation and technical requirements for the promotion of social integration.

The lack of citizens' participation was also evident, thus it is important to implement measures to increase their involvement in the decisions affecting their lives on a daily basis. To this end, local authorities should promote public debates and discussions about the accessibility conditions.

It is possible to transform these weaknesses of local authorities into opportunities if their intervention is directed towards maintaining an inclusive society and fighting against social isolation and discrimination, where everyone can participate in the social, political, professional, and family life.

Therefore, rehabilitation nursing care faces new challenges and horizons within an increasingly complex and multidimensional context. Rehabilitation nurses should promote the development of strong health policies by influencing political, technical, and social decisions with a view to promoting accessible environments. Given that the lack of training was one of the difficulties reported in this study, this can be achieved mainly by training and raising parish council presidents' awareness about the importance of eliminating architectural barriers and respecting and valuing human diversity so that people with reduced mobility can fully participate in society. The local municipal bodies are the political agents who are responsible for building inclusive territories for people with reduced mobility.

Future studies should replicate this study in other municipalities, use observational designs to identify architectural barriers in buildings, central and local government facilities and areas, public institutes, and public roads, as well as characterize the architectural accessibility in the residential context, for example among older people living in social housing.

\section{References}

Almeida, J. N., Ferreira, A., \& Figueiredo, J.P. (2008). Barreiras arquitetónicas no acesso a serviços públicos. In A. Ferreira (Ed.), Ciência, saúde e inovaçâo. Investigação aplicada em Saúde Ambiental (pp. 7-21). Coimbra, Portugal: Escola Superior de Tecnologia da Saúde de Coimbra.

Bárrios, M. J., \& Fernandes, A. A. (2014). A promoção do envelhecimento ativo ao nível local: Análise de programas de intervençấo autárquica. Revista Portuguesa de Saúde Pública, 32(2), 103-108. Retrieved from https://www.sciencedirect.com/science/article/pii/ S0870902514000492.

Decreto-Lei no 163/2006 de 8 de Agosto. Diário da República $n^{\circ}$ 152/06, I Série. Ministério do trabalho e da Solidariedade Social. Lisboa, Portugal.

Falcato, J. (2017). Autarquias e inclusão das pessoas com deficiência. Retrieved from http://www.esquerda.net/ artigo/autarquias-e-inclusao-das-pessoas-com-deficiencia/50202.

Fontes, F., \& Martins, B. S. (2015). Deficiência e inclusão social. Os percursos da lesão medular em Portugal. Sociologia, Problemas e Práticas, 77(1), 153-172. Recuperado de http://journals.openedition.org/spp/1890.

Gallo, E. C., Orso, K. D., \& Fiório, F. B. (2013). Análise da acessibilidade das pessoas com deficiência física nas escolas de Chapecó-SC e o papel do fisioterapeuta no ambiente escolar. O Mundo da Saúde, 35(2), 2012017. Retrieved from http://bvsms.saude.gov.br/bvs/ artigos/analise_acessibilidade_pessoas_deficiencia_fisica_escolas.pdf.

Gamache, S., Routhier, F., Morales, E., Vandersmissen, M. H., Leblond, J., Boucher, N., ... Noreau, L. (2017). Municipal practices and needs regarding accessibility of pedestrian infrastructures for individuals with physical disabilities in Québec, Canada. Journal of Accessibility and Design for All, 7(1), 21-55. Retrieved from https://www.jacces.org/index.php/jacces/article/ view/122.

Government of Ontario. (2015). Planning for barrier-free municipalities. Retrieved from http://www.mah.gov. on.ca/Page1290.aspx.

Instituto Nacional de Estatística. (2012). Censos 2011 - Resultados definitivos. Lisboa, Portugal: Autor.

Instituto Nacional de Reabilitação. (2010). Decreto-Lei nº163/2006. Lisboa, Portugal: Autor. 
Lima, S. S., Carvalho-Freitas, M. N., \& Santos, L. M. (2013). Repercussóes psicossociais da acessibilidade urbana para as pessas com deficiência física. Psicologia, 44(3), 362-371. Retrieved from http://revistaseletronicas.pucrs.br/ojs/index.php/revistapsico/article/ view/15823/10411.

Pereira, L. M., Caribé, D., Guimarães, P., \& Matsuda, D. (2011). Acessibilidade e crianças com paralisia cerebral: A visão do cuidador primário. Fisioterapia em movimento, 24(2), 299-306. Retrieved from http:// www.scielo.br/pdf/fm/v24n2/a11v24n2.pdf.

Perestrelo, M. (2012). Prospetiva e democracia participativa: Sucessos e insucessos. In A. P. Marques, \& R. Moreira (Eds.), Governação e territorialidades. Lógicas e práticas na administração local (pp. 95-113). Braga, Portugal: Edições Húmus.

Regulamento no 125/2011 de 20 Novembro. Diário da
República no 35/11, II Série. Ordem dos Enfermeiros. Lisboa, Portugal.

Szporluk, M. (2015). The right to adequate housing for persons with disabilities living in cities. UN-Habitat for a better urban future. Retrieved from https://unhabitat. org/books/the-right-to-adequate-housing-for-persons-with-disabilities-living-in-cities/.

Tavares, S., Rodrigues, M. J., \& Silva, J. F. (2013). Perfil do Autarca: Caracterização dos eleitos locais 2013. Retrieved from https://www.sg.mai.gov.pt/AdministracaoEleitoral/Publicacoes/SociologiaEleitoral/Documents/Perfil\%20do\%20Autarca2013.pdf.

Wennberg, H., Stahl, A., \& Hydén, C. (2009). Implementing accessibility in municipal planning: planner's view. Journal of Transport and Land Use, 2(2), 3-21. Retrieved from https://www.jtlu.org/index.php/jtlu/ article/view/36/60. 